\title{
Aplikasi Absensi Pegawai Kecamatan Batuceper Tangerang Dalam Meningkatkan Akurasi Informasi
}

\author{
Rachman Mulyandi ${ }^{1}$ \\ CynthiaAyu Wulan Dini \\ e-mail :rachman@raharja.info,cynthia@raharja.info
}

Diterima : 04 Desember 2013 / Disetujui: 13 Desember 2013

\begin{abstract}
Subdistrict Batuceper a government agency employee attendance system is still running it manually. Where the application of the attendance system there are some things that become obstacles. The problems that occur are in terms of effectiveness, efficiency and process time of roll call . Attendance report form which is currently still in the form of writing that can complicate the search process the data, and the possibility of missing attendance data. With the above reasons, the author tries to provide alternative solutions to the problem by creating an application that will record attendance system employee attendance, time of arrival, time of return, which will be made in a systematic and computerized. This system eliminates the process of recording employee attendance that still run manually, ie by reducing the error rate by means of input personal identification number in the attendance process . At this writing will also be explained stages of processing, ranging from process analysis , planning, design using the programming language PHP ( Hypertext Prepocessor ) and MySQL database, until the implementation stage using spiral with engineering notation and object -oriented approach , UML ( Unified Modeling Languange ), in order to determine what data is being input and output on the system running. With the attendance information system is expected to minimize the constraints that occur in the system before.
\end{abstract}

Keywords : Absence, Attendance Information Systems , UML

1. Dosen Jurusan Sistem Informasi, STMIK Raharja

Jl. Jend Sudirman No. 40 Modern Cikokol-Tangerang Telp. 5529692

2. Mahasiswa Jurusan Sistem Informasi, STMIK Raharja

Jl. Jend Sudirman No. 40 Modern Cikokol-Tangerang Telp. 5529692

3. Mahasiswa Jurusan Sistem Informasi, STMIK Raharja

Jl. Jend Sudirman No. 40 Modern Cikokol-Tangerang Telp. 5529692 


\section{ABSTRAKSI}

Kecamatan Batuceper merupakan instansi pemerintahan yang sistem absensi pegawainya masih berjalan secara manual. Dimana dalam penerapan sistem absensi ini terdapat beberapa hal yang menjadi kendala. Adapun kendala yang terjadi yaitu dalam hal keefektifan, efisiensi waktu dan proses pengabsenan. Bentuk laporan absensi yang ada saat ini masih berupa tulisan yang dapat menyulitkan dalam proses pencarian data, dan kemungkinan terjadinya data absensi yang hilang. Dengan alasan di atas maka penulis mencoba untuk memberikan alternatif pemecahan masalah dengan membuat suatu aplikasi sistem absensi yang akan mencatat daftar kehadiran pegawai, waktu kedatangan, waktu pulang, yang akan dibuat secara sistematis dan terkomputerisasi. Sistem ini menghilangkan proses pencatatan kehadiran pegawai yang selama ini masih berjalan secara manual, yaitu dengan mengurangi tingkat kesalahan dengan cara menginputkan nomor induk pegawai dalam proses absensi tersebut. Pada penulisan ini juga akan diterangkan tahapan pengerjaan, mulai dari proses analisa, perencanaan, perancangan dengan menggunakan bahasa pemograman PHP (Hypertext Prepocessor) dan database MySQL, hingga tahapan pengimplementasian dengan menggunakan metode spiral dengan notasi perekayasaan dan pendekatan berorientasi objek, UML (Unified Modelling Languange), dengan tujuan untuk mengetahui data apa saja yang menjadi masukan dan keluaran pada sistem yang berjalan. Dengan adanya sistem informasi absensi ini diharapkan dapat meminimalkan kendala-kendala yang terjadi pada sistem sebelumnya.

Kata Kunci : Absen, Sistem Informasi Absensi, UML

\section{PENDAHULUAN}

Kecamatan Batuceper merupakan salah satu perangkat daerah kota sebagai pelaksana teknis kewilayahan yang mempunyai wilayah kerja tertentu yang terbentuk berdasarkan Perda 7 Tahun 2008 tentang Organisasi Kecamatan dan Kelurahan, serta memegang peran yang strategis dalam pelayanan kepada masyarakat dan penyelenggaraan tugas umum pemerintahan.

Dalam suatu instansi memerlukan kebijakan terutama dilihat dari kedisiplinan pegawai dan totalitas dalam bekerja. Kedisiplinan pegawai merupakan tolak ukur dalam melihat kinerja setiap pegawai. Salah satu unsur penting dalam menilai kinerja setiap pegawai adalah absensi atau presentase tingkat kehadiran. Absensi merupakan fungsi penting yang menjadi tanggung jawab Bagian Kepegawaian.

Pada Kecamatan Batuceper proses absensi yang berjalan saat ini masih dilakukan secara manual dalam hal proses pengolahan data absensi pegawai. Maka dari itu sering terjadi kecurangan pada proses absensi seperti penitipan absen dan pulang sebelum jam kerja berakhir. Proses pengolahan data yang lambat dapat mengakibatkan lambatnya penyampaian informasi. Oleh sebab itu diperlukan sistem 
infromasi yang dapat memecahkan masalah tersebut yang cepat dan akurat.

Dari permasalahan yang timbul maka dibuatlah sebuah sistem informasi absensi untuk memudahkan proses absensi pegawai. Sistem informasi absensi merupakan upaya dari diusulkannya sistem ini bertujuan untuk memberikan keefektifan dan efisiensi waktu dan proses pengabsenan, selain itu untuk meningkatkan kinerja pegawai sehingga tidak terjadinya kecurangan pada saat jam kerja.

\section{PERMASALAHAN}

Dalam studi kasus dibagian kepegawaian pada Kecamatan Batuceper Tangerang ini, penulis menemukan masalah yang bisa terselesaikan dengan adanya dukungan dari sistem informasi yang baik. Permasalahan yang ada di Kecamatan Batuceper adalah proses absensi yang berjalan pada Kecamatan Batuceper masih dilakukan secara manual dalam hal proses pengolahan data absensi pegawai. Maka dari itu sering terjadi kecurangan pada proses absensi seperti penitipan absen dan pulang sebelum jam kerja berakhir. Proses pengolahan data yang lambat dapat mengakibatkan lambatnya penyampaian informasi. Berdasarkan pada permasalahan diatas, maka diperlukan adanya sistem informasi absensi yang dapat meminimalkan permasalahan ada, yaitu dengan membangun sistem yang dapat membantu bagian kepegawaian dalam melakukan proses pengolahan data dan membantu para pegawai dalam melakukan proses absensi.

\section{PEMBAHASAN}

Pada penelitian ini, penulis akan membahas tentang sistem informasi absenisi yang ada pada Kecamatan Batuceper proses absensi yang berjalan yang ada saat ini masih dilakukan secara manual dalam hal proses pengolahan data absensi pegawai. Maka dari itu sering terjadi kecurangan pada proses absensi seperti penitipan absen dan pulang sebelum jam kerja berakhir. Proses pengolahan data yang lambat dapat mengakibatkan lambatnya penyampaian informasi. Oleh sebab itu diperlukan sistem infromasi yang dapat memecahkan masalah tersebut yang cepat dan akurat.

Penulis mengusulkan sistem informasi absensi yang dapat membantu para pegawai dalam melakukan absen, terutama pada bagian kepegawaian yang akan sangat membantu dalam proses pengolahan data absensi. Dimana sistem yang dibangun ini pada proses absensinya hanya memasukkan NIP pada saat absen, dan secara otomatis akan terdaftar pada tabel absensi pegawai. 
Pada penulisan jurnal ilmiah ini, pembahasan akan menitikberatkan pada poinpoin berikut:

1 Prototype perancangan sistem informasi absensi pegawai pada Kecamatan Batu Ceper, Tangerang.

2 Proses atau alur kegiatan absensi pegawai baik pada waktu kehadiran dan juga pada waktu pulang.

3 Perhitungan absensi pegawai yang dilakukan rutin setiap bulannya, yang dimana perhitungan ini akan dijadikan laporan absensi pegawai sebagai bahan pertimbangan untuk pengambilan keputusan kinerja pegawai dalam hal kedisiplinan waktu.

\section{LITERATURE REVIEW}

Banyak penelitian yang sebelumnya dilakukan mengenai sistem informasi absensi. Dalam upaya pengembangan sistem informasi absensi ini diperlukan studi pustaka sebagai salah satu dari penerapan metode penelitian yang akan dilakukan. Diantaranya adalah menganalisa kebutuhan, desain, pemograman, pengujian dan penginstalan, serta mengetahui orang lain yang spesialisasi dan area penelitiannya sama dibidang ini. Beberapa literature review tersebut adalah sebagai berikut :

1 Penelitian yang dilakukan oleh Untung Rahardja, Mukti Budiarto, Maimunah dari Perguruan Tinggi Raharja yang berjudul “Absensi Online”. Penelitian ini membahas mengenai pelayanan absensi secara online. Dengan adanya absensi online dapat meningkatkan mutu perkuliahan dalam proses belajar mengajar pada Perguruan Tinggi Raharja serta sebagai akses publikasi pada tingkat Nasional dan Internasional pada umumnya. Selain itu sistem pengembangan dari sistem Absensi Online juga adalah merupakan komitmen dari Perguruan Tinggi dalam meningkatkan mutu kegiatan belajar mengajar baik untuk dosen maupun mahasiswanya, serta meningkatkan mutu pelayanan terhadap civitas perguruan tinggi dan peningkatan kinerja staf perguruan tinggi raharja.

2 Nevertety F. Papilaya, Inne Gartina Husein, N.Ali Hanifa dari Politeknik Telkom Bandung yang berjudul "Aplikasi Absensi dan Penggajian Pegawai”. Penelitian ini membahas mengenai perhitungan jam kerja dan gaji karyawan setiap bulanan. Pada penelitian ini penulis membangun aplikasi absensi dan penggajian pegawai berbasis web untuk memudahkan dari pihak kepegawaian dalam mengelolah data absensi dan pihak keuangan dalam menghitung 
tambahan penghasilan para pegawai. Sistem yang dibangun menggunakan bahasa pemograman PHP dan HTML yang digunakan untuk membuat suatu situs web atau homepage. Kelebihan dari aplikasi sistem ini yaitu, absensi dan penggajian karyawan ini dapat membantu pegawai BPMPD dalam mencatat presensi pegawai secara tepat waktu, dapat menyajikan data yang akurat dan lengkap, serta dapat membantu membuat laporan data tambahan penghasilan dan data presensi pegawai setiap bulannya.

3 Kartika Elisabeth, Eka Widhi Yunarso, Budi Laksono Putro dari Politeknik Telkom Bandung yang berjudul "Jurnal Sistem Informasi Absensi dan Penggajian Pegawai”. Penelitian ini membahas mengenai pengembangan sistem absensi dan penggajian. Pada penelitian ini sistem yang dikembangan menggunakan bahasa pemograman Java dan client server sebagai arsitektur dimana client sebagai perangkat yang menerima dan menjalankan aplikasi sedangkan server perangkat yang menyediakan dan bertindak sebagai pengolah aplikasi data dan keamanannya. Kelebihan dari sistem ini memiliki sistem absensi yang berkaitan dengan penggajian, dimana sistem penggajian yang dibuat bisa memberikan laporan yang cepat dan akurat. Adapun kekurangan dari sistem ini adalah tidak adanya menu report (laporan) tentang absensi dan penggajian yang dapat ditampilkan secara lengkap perhari, perminggu, bulan ataupun pertahun.

4 Catur Fifty Anas Sari, Lies Yulianto dari Universitas Surakarta berjudul "Perancangan Sistem Informasi Absensi Menggunkaan Finger Print di Badan Perencanaan Pembanguna Daerah dan Penanaman Modal Kabupaten Pacitan”. Permasalahan yang ada pada sistem absensi pegawai di Badan Penrencanaan Pembangunan Daerah dan Penanaman Modal Kabupaten Pacitan masih dilakukan secara manual dengan melakukan absensi tanda tangan pada kertas dan juga terdapat kecurangan para pegawai yang menitipkan tanda tangan absensinya. Dari permasalahan tersebut maka dibuatlah sistem absensi menggunakan finger print dengan tujuan untuk menerapkan aplikasi yang mudah digunakan dengan hasil yang maksimal dan cara pemakaiannya yang mudah. Pembuatan aplikasi ini menggunakan database sebagai proses penyimpan data. Kelebihan dari sistem ini dapat meningkatkan kedisiplinan dalam mengemban tugas.

\section{PEMECAHAN MASALAH}

Untuk mengatasi permasalahan seperti yang telah dijelaskan diatas, maka 
dibutuhkan sistem absensi yang dapat meminimalkan permasalahan yang ada. Sistem informasi absensi merupakan salah satu upaya untuk membantu kelancaran instansi sehingga data yang di dapat lebih tepat dan akurat. Sistem ini akan menghilangkan proses pencatatan kehadiran pegawai yang selama ini masih berjalan secara manual, yaitu dengan mengurangi tingkat kesalahan penginputan nomor induk pegawai dalam proses absensi tersebut. Didalam sebuah sistem informasi absensi yang berbasis web, dimana semua data yang ada tersimpan didalam suatu database. Maka selama proses absensi dilakukan pada saat jam masuk dan pulang tersimpan didalam database dan sistem absensi yang akan dibangun ini menggunakan rancangan sistem dengan bahasa pemograman PHP (Hypertext Preprosessor) dan database MySQL.

Berikut ini adalah gambaran mengenai tahap absensi pegawai. Dimana tiap pegawai melakukan input NIP pada saat jam masuk dan jam pulang, kemudian bagian kepegawaian membuka data laporan absensi untuk melakukan rekap absen dan cetak laporan.

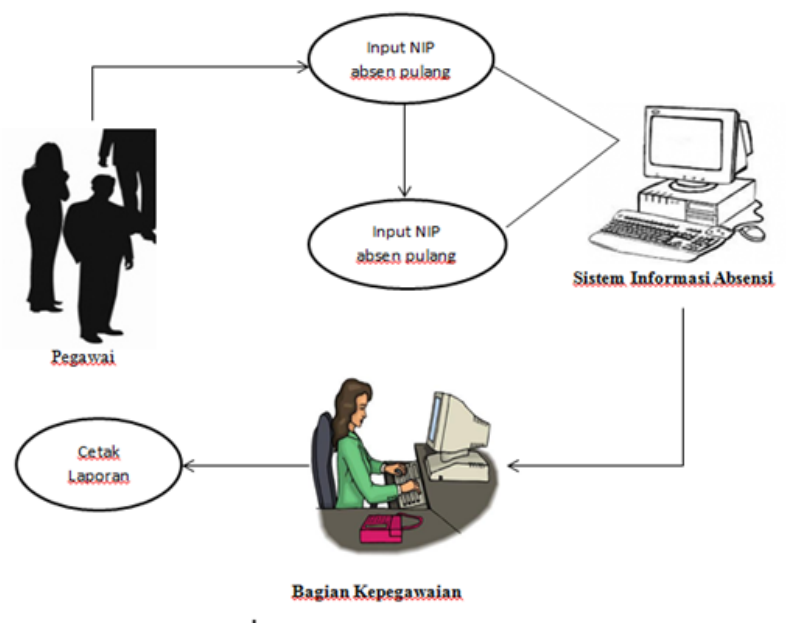

Gambar 1. Siklus Tahap Absensi

\section{ANALISA SISTEMABSENSI}

Untuk membangun sebuah sistem maka diperlukan rancangan yang diagram untuk memudahkan dalam melakukan rancangan sistem agar sistem yang dibuat dapat terstruktur, rancangan sistem ini dibuat menggunakan UML (Unified Modeling Language). 


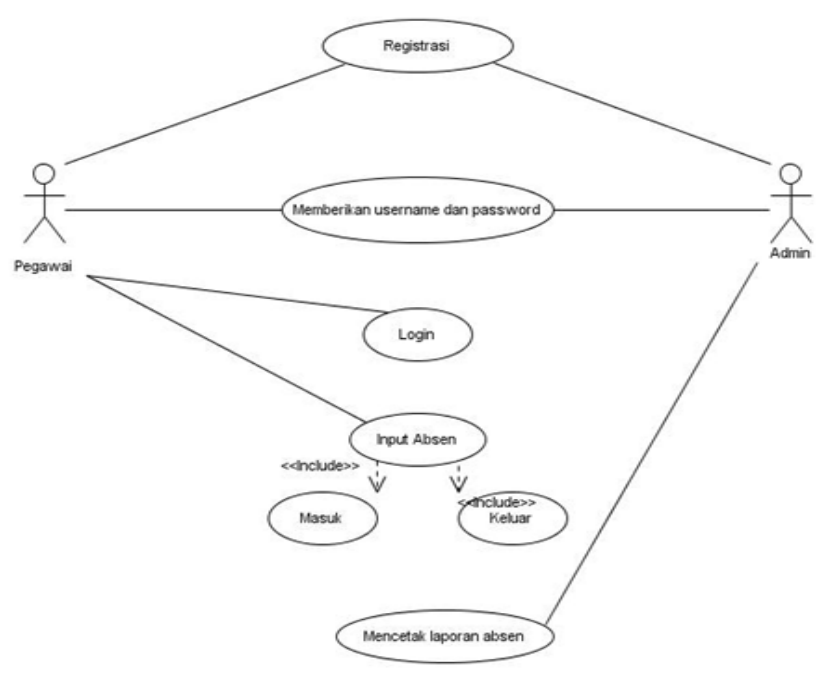

Gambar 2. UML Sistem Informasi Absensi

\section{IMPLEMENTASI}

Untuk dapat mengakses Sistem Informasi Absensi cukup mengetik pada windows explorer ruang kosong address dengan mengetik http:/localhost/absensi yang kemudian akan muncul tampilan menu login seperti dibawah ini.

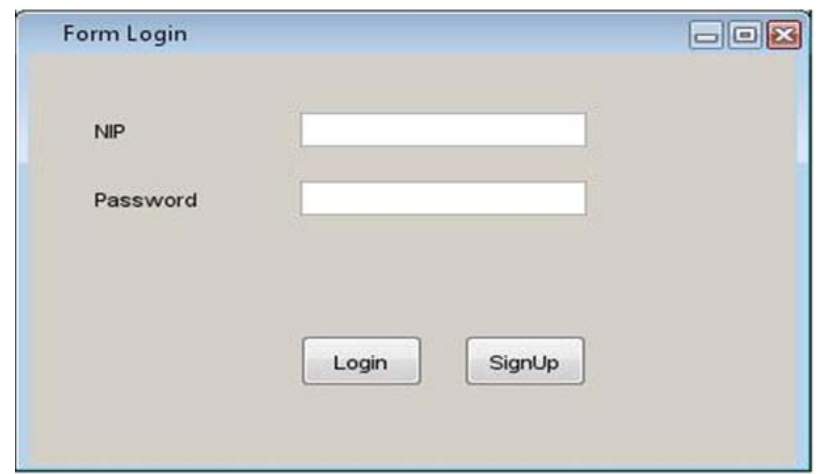

Gambar 3. Rancangan Form Login

Form login digunakan oleh admin dan seluruh pegawai yang ada di Kecamatan Batuceper jika sudah memiliki akun untuk login. Jika pegawai belum memiliki akun 
maka klik tombol signup untuk melakukan registrasi terlebih dahulu, pada saat mengklik tombol login maka akan muncul daftar menu registrasi seperti dibawah ini.

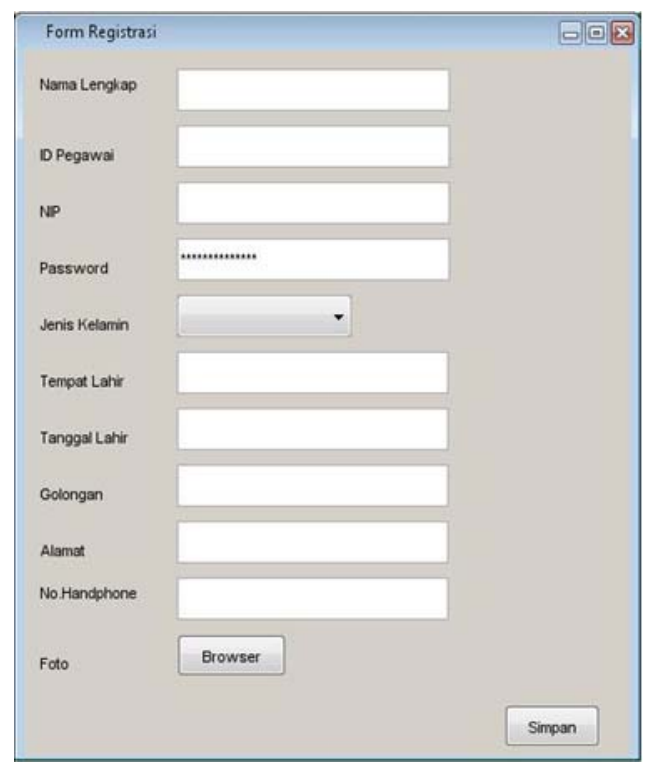

Gambar 4. Rancangan Form Registrasi Pegawai

Form registrasi digunakan jika pegawai belum memiliki akun untuk login. Pada form registrasi yang dapat menginputkan hanya bagian admin saja, maka bagian admin akan menginput data pegawai yang belum memiliki akun. Setelah selesai klik tombol simpan, maka akan muncul notification jika data berhasil disimpan. Jika gagal maka akan kembali pada menu form registrasi pegawai. Berikut ini tampilan dari notification.

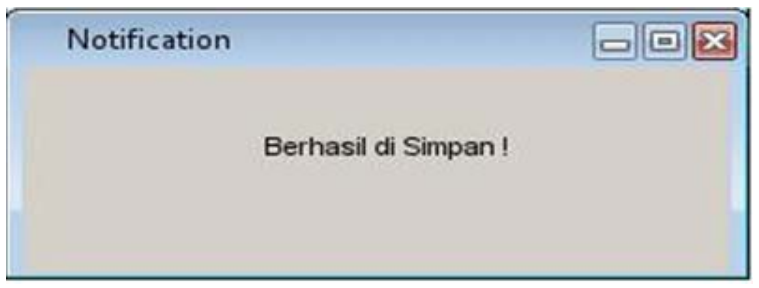

Gambar 5. Rancangan Notification Data Berhasil Disimpan

Pada saat proses penyimpanan berhasil, maka data pegawai tersimpan dalam 
form daftar pegawai seperti dibawah ini.

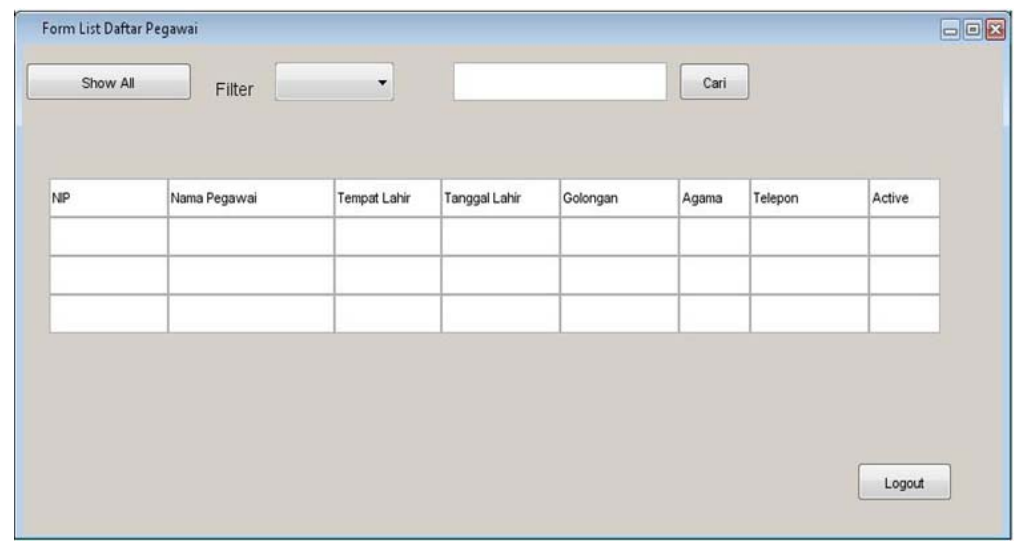

Gambar 6. Rancangan Form Daftar Pegawai

Setelah selesai maka pilih tombol logout. Selanjutnya bagian admin memberikan username dan password kepada setiap pegawai untuk melakukan login terlebih dahulu sebelum melakukan absen. Jika pegawai sudah melakukan login maka akan muncul menu absensi pegawai, seperti dibawah ini.

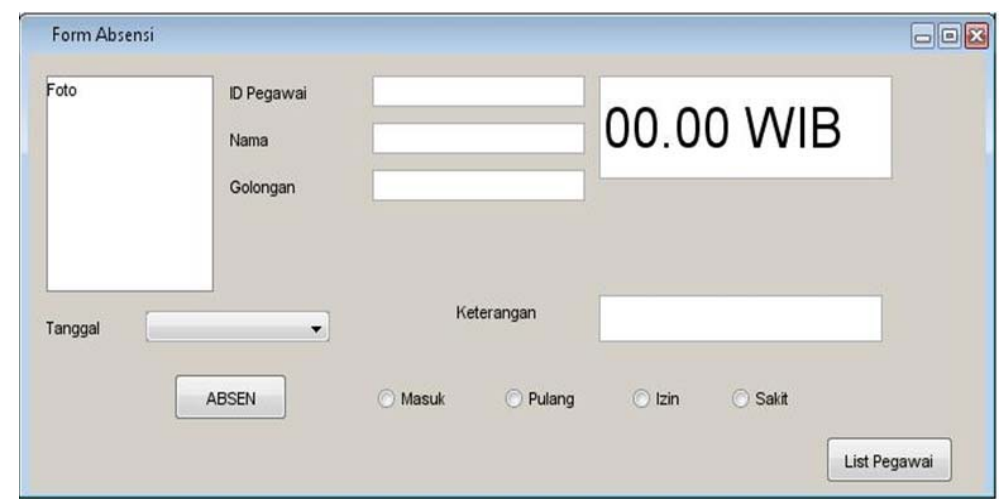

Gambar 7. Rancangan Form Sistem Absensi Pegawai

Pada saat pegawai ingin melakukan absen, pegawai harus menginputkan ID pegawai terlebih dahulu, kemudian akan muncul nama , golongan serta foto. Setelah itu pegawai mengklik radio button onfield untuk memilih absen masuk, pulang, izin, atau sakit. Jika terlambat masuk atau izin maka pegawai harus memberikan alasan 
pada kolom keterangan, kemudian klik tombol absen maka absensi telah terdaftar pada form list absensi. Combo box tanggal digunakan jika pegawai tidak bisa absen masuk atau kemarin tidak melakukan absen dengan cara merubah tanggal pada combo box, dan beri keterangan pada kolom yang tersedia, dan sebaliknya jika ingin absen untuk hari ini maka tanggal harus dirubah kembali sesuai tanggal hari ini. Jika ingin melihat daftar absensi, pegawai memilih tombol list pegawai, maka akan muncul form list pegawai, seperti dibawah ini.

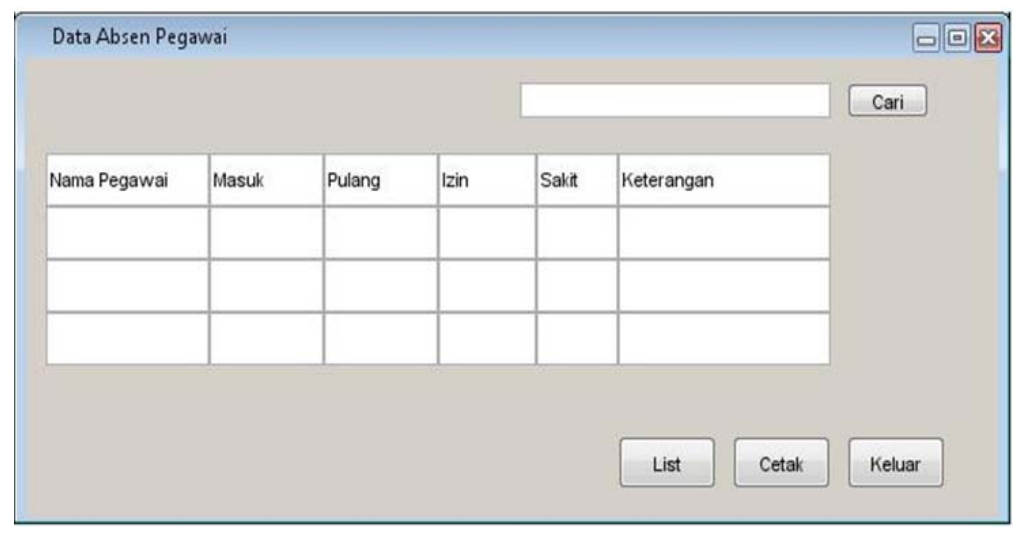

Gambar 8. Rancangan Form Daftar Absen Pegawai

Form data absen dapat dicetak untuk laporan harian dan bulanan, jika hanya ingin salah satu pegawai saja yang ingin dicetak maka letakkan kursor pada nama pegawai yang ingin dicetak. Kemudian akan muncul form laporan absensi pegawai. Berikut ini contohnya.

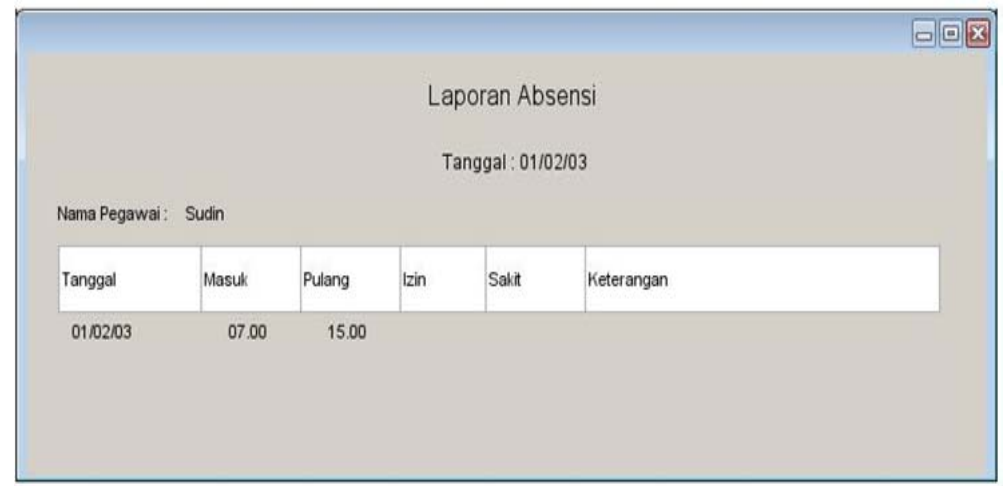

Gambar 9. Rancangan Form Laporan Absensi 


\section{KESIMPULAN}

Sistem informasi absensi pada Kecamatan Batu Ceper adalah merupakan suatu implementasi penggunaan sistem informasi yang khusus di desain dan diterapkan guna meningkatkan kedisiplinan pegawai untuk dapat lebih menghargai waktu dalam proses perkuliahan. Selain itu sistem yang telah dirancang ini mampu memberikan kemudahan dalam hal pelaporan terutama oleh bagian Umum dan Kepegawaian sehingga sesegera mungkin mengambil tindakan yang dianggap perlu dalam melakukan pembinaan terhadap pegawai yang dianggap melanggar tata tertib dan kedisiplinan dalam bekerja.

\section{DAFTAR PUSTAKA}

[1] Catur Fitri Anas Sari, Yulianto Lies . Perancangan Sistem Informasi Absensi Menggunakan Finger Print di Badan Perencanaan Pembangunan Daerah dan Penanaman Modal Kabupaten Pacitan. Surakarta: Universitas Surakarta., Seminar Riset Unggul Nasional dan Informatika dan Komputer, Vol 2 No.1, Maret 2013.

[2] Elicabeth Kartika, Yunarso Widhi Eka, Putra Laksono Budi. Sisthttp://submission-ccit.ilearning.me/wp-admin/post.php?post=100\&action=editem Informasi Absensi dan Penggajian Pegawai. Bandung: Politeknik Bandung. 2009

[3] Nugroho, Adi. Rekayasa Perangkat Lunak Menggunakan UML dan Java, Yogyakarta: Andi Offset.2010.

[4] Papilaya F Neverty, Gartira Inne Husein, Hanifa Ali N. Aplikasi Absensi dan Penggajian Pegawai. Bandung: Politeknik Bandung. 2006

[5] Rahardja Untung, Budiarto Mukti, Maimunah . Absensi Online. Tangerang: Perguruan Tinggi Raharja,, pp. 83-94, Journal CCIT, Vol.1 No.2, Mei 2008.

[6] Perguruan Tinggi Raharja. Manual BookAbsensi Online. Tangerang : Perguruan Tinggi Raharja. 